Journal of Management and Development Studies Vol. 25(1):59-81

Available online http://nasc.org.np

(C2013 Nepal Administrative Staff College

\title{
Socio-economic impact of microfinance in Nepal
}

\author{
Narayan Prasad Paudel \\ Assistant Professor, Kathmandu University School of Management \\ Email: narayan@kusom.edu.np
}

Accepted 25 July 2013

The microfinance institutions (MFIs) in Nepal are constrained in capacity of key technical areas essential to rural finance operations such as accounting, auditing, strategic planning, financial analysis, and portfolio management. This lack significantly limits their potential to expand their client base and outreach to poor households. The number of MFIs with private sector's participation is expanding significantly. The overall impression of microfinance performance indicates that the microfinance clients, the loan portfolio outstanding, and savings are in increasing trend. Despite these efforts, the level of poverty remains unchanged across the rural households. As a measure of effect of microfinance, with the rise in membership duration, cooking fuel status of the clients is yet to be improved. The current monthly income of control group households is in declining trend at present. The rate of increase in monthly income of experimental group is quite high for the majority of the respondents. The household food sufficiency from household production is more pronounced in experimental group than in the control group. The contribution of other incomes in determining the total income of households is more significant in comparison to agricultural and farm related income raise through the microcredit facilities. The status of female child enrollment in private school has significantly increased irrespective of the level of earning of households.

Key words: Microfinance, income, expenditure, experimental group, poverty

\section{Introduction}

The origin of microfinance can be traced back to 1976, when Muhammad Yunus set up the Grameen Bank, as an experiment, in Bangladesh. Since then several microfinance institutions have come and succeeded in reaching the poorest of the poor, and have devised new ground-breaking strategies over time. Rural Financial Sector Analysis (RFSA) outlines that as of mid July 2009, there were 547,000 group members and 436,000 borrowers were enrolled in Micro Credit Development Banks in Nepal (Asian Development Bank [ADB], 2010). Commercial banks and other financial institutions are also providing deprived sector credit to the poor, directly or indirectly, through cooperatives and NGOs, consequently, it is estimated that nearly 400,000 poor people are enjoying microcredit facilities. Microfinance clients, the loan portfolio outstanding and 
savings are in increasing trend, the loan outstanding in MFDBs is growing rapidly and it reached to Rs. 9,795,232 thousand in Mid-July 2010.

As stated in Nepal Rastra Bank [NRB] (2008), the formal microfinance sector in Nepal started in 1974, when NRB directed Nepal Bank Limited (NBL) and Rastrya Banijaya Bank (RBB) to lend at least 5 percent of their deposits under a "priority sector credit" scheme. The target sectors under the scheme include agriculture, cottage industries and services. NRB (2008) outlined that for nearly four decades, various agencies in Nepal have been active in microfinance with the central bank of Nepal, playing a pivotal role in policymaking decisions.

The ADB (2010) states that NRB is responsible for licensing, regulating and supervision of banks and financial institutions along with financial intermediaries. The main objective of regulation on micro finance is to ensure the sustainability of micro finance institutions in order to maintain continuous micro finance services to rural poor. To ensure regular financial services to the poor with easy and affordable cost, NRB introduced deprived sector credit for banks and financial institutions. NRB has made the provision of deprived sector credit directives under unified directives. NRB further stressed that financial instability hurts the poor most.

Microfinance Focus (2009) reports that extreme poverty affects at least 10 per cent of the population in many parts of the Asia and Pacific region. The report lists 19 economies, where more than 10 percent of the populations were living on less than $\$ 1.25$ a day in the subsequent year. The report further highlights that six of the 19 economies are from the former Soviet Union. It also reveals that five of the economies China, Pakistan, Tajikistan, Turkmenistan, and Vietnam have at least halved the percentages of their population living on less than \$1.25 a day while four other economies - Georgia, Kyrgyz Republic, Mongolia, and Uzbekistan — have experienced rising poverty rate.

Banerjee, Duflo, Glennerster \& Kinnan (2009) evaluated the impact of introducing microcredit in a new market. It presents results of a study in Hyderabad, India involving a sample of 104 slums. They have concluded that in short-term, microcredit may not be the miracle that it is sometimes claimed to be. It, however, does allow households to borrow, invest, and create and expand businesses.

Dhakal (2007) has outlined that the size of the potential market matters in defining appropriate role for the state in developing microfinance sector. Geographical aspects and population density influences the size of potential market and significantly determines the role of the state. 
Socio-economic impact of microfinance in Nepal

\section{Statement of the problem and rationale of the study}

The microfinance industry is characterized by too many small-scale suppliers with a relatively large potential market. A majority of small-scale service providers are unable to diversify their risks adequately across space and activities that they finance.

In case of Nepal, the rule to keep 10 percent of a bank's reserves specifically for microfinance has largely been ignored and a fine has already been paid as consequence. It is widely believed to be the result of general banking trend of spending the bank resources with large investments that have more secure payout than dealing with a population that are generally under educated, more likely to default on their loan and yield much lower return on investment. In spite of gradual development of microfinance activities in Nepal, still the country has experienced some fundamental problems and issues in microfinance including problems in identifying target groups, identifying potential projects that can be easily managed by the client's needs, misunderstanding about the interest rates used by some MFIs, lacking coordination across the MFIs and lacking of microfinance related trainings to the clients. Despite the long history of microfinance and the large number of institutions involved in providing microfinance facilities in Nepal, their effectiveness in alleviating poverty in the country is not clear. Though there are few studies on the impact of microfinance on households' level in Nepal, yet there is room for exploring the wider dimension on effects of microcredit on the living standards of households. Hence, the current study attempts to fill the current gap in identifying the effects of microfinance on various socio-economic dimensions of microfinance clients. The current study examines the movements in level of households' expenditure and income along with net saving of households. It is very imperative to examine the existing domestic problems of microfinance and to create awareness on the microfinance program and promote co-operation among all types of stakeholders at national and local level.

\section{Objectives}

The broad objective of the article is to explore the effects of microfinance in socio-economic status of Nepalese households. Specific objectives of the article are to examine the effects of microfinance on living standards of household, to explore the level of changes in households' income, net savings and household expenditure pattern, to examine the volume of asset acquired by microfinance clients (land ownership status) and to examine the effects of microfinance on child education and welfare of the clients. 
Socio-economic impact of microfinance in Nepal

\section{Framework on data management}

The researcher surveyed both MFIs and clients across the various region of the country. The researcher conducted survey and collected different category of primary data. The research team collected data from public sources and experts in the region. In the first attempt, researcher identified the majority of organizations that provided microfinance services. Researcher primarily focused on primary sources of data and considered secondary sources of data as per the need of the study. The researcher asked questions about the effects of the loans that the respondents had received in terms of income, consumption, assets and many other areas. The questions were all asked at the same time and referred to details from the past year and from two years ago. The questions that were particularly useful for this study were the ones that pertained to status of dwelling, fuel consumption, qualities of drinking water, child's enrollment status, household expenditure and income changes, initial loan amount and severity of households' business problems.

\section{Data sample and limitations}

The researcher identified NGOs and rural microfinance institutions, commercial banks, and microfinance banks that provide microfinance services across the region of the country. In addition to the survey, data is gathered from publicly available sources, such as organizational web sites and annual reports, and from supporting organizations, such as the Rural Microfinance Development Center (RMDC), NRB. Data on the overall size and outreach of the microfinance industry was based on a large, fairly representative sample.

The scope of the study is strictly confined only to three different districts including Kaski, Banke and Surkeht. Researcher primarily confined on socioeconomic aspects of microfinance. The study has pooled the opinion of 91 microfinance experts and practitioners from across the various representative microfinance institutions.

\section{Research design}

One of the most important aspects of microfinance is economic and social empowerment, which is discussed in detail during the study. Besides these, effective source of borrowing, interest rate structure, purpose of saving, severity of microfinance problems, major income activities of the MF clients are also discussed and analyzed. The researcher has used the blend of descriptive as well as analytical research design to make the research more simple and understandable. The current study is a survey based descriptive study on the present socio-economic conditions of microfinance subscribers. 
Socio-economic impact of microfinance in Nepal

\section{Procedure of data collection and analysis}

Specifically, the study has initiated an effort to reach out to the grass-root level and engage microfinance clients in defining the impact of microfinance as a poverty alleviation strategy and clients welfare improvement. In order to examine the relationship between human development/poverty alleviation and microfinance, both quantitative and qualitative methods have been used. Stratified sampling is used to choose the respondents. Samples were drawn from three districts (Kaski, Banke and Surkeht) using stratified sampling technique. Similarly, all the questions were asked at the same time and referred to details one and two-years preceding the study respectively. Open ended and close ended questionnaire were used in identifying quantitative as well as qualitative aspects of microfinance performance. The data used in the study was cross sectional collected in the year 2010. Questions were asked about the effects of the loans that the respondents had received in terms of income, consumption, assets and many other areas.

\section{Analysis tools}

The methodology for carrying out quantitative and qualitative field research included a variety of research tools such as percentage, mean, standard deviation, linear regression and multiple regression, correlation and correlation matrix, coefficient of determination ( $\mathrm{R}$ squared) and variance of standard error. In few of the cases, an experimental and control group are categorized in which the implementation of the program in experimental area and with no exposure to the program in the control group was compared.

Various indicators were used to identify the relationships among variables. First, a set of indicators that are strongly tied to poverty levels were identified; next the survey was designed to collect the needed indicators from individual households; and finally, the data were summarized for comparisons. Examples of the indicators those are used in the study include the type or quality of housing, and amount of wealth or assets.

\section{Data and results}

\section{Level of households earning and food sufficiency}

The household food sufficiency for experimental group households increased by more than 11 months, for 55 percent of households, when their level of income increased up to 25 percent, followed by 21 percent of households, who have food access for more than 11 months, despite their current level of monthly income stayed the same, in comparison to one year preceding income. The result further indicates that when the level of income increased up to 25 percent for 45 percent 
of households (out of 20 households), food sufficiency could be noticed for less than 3 months. Same is the case for 20 percent of households (out of 20 households) where the monthly income increased by 25-50 percent in comparison to one year preceding monthly income. The case of control group is different, where the household's food sufficiency from household production increased by 8-10 months when the level of income of control group households increased by 2550 percent for the majority of households. The above results lead to the conclusion that the household food sufficiency from household production is more pronounced in experimental group (microcredit beneficiaries) than in the control group (non beneficiaries of microcredit).

\section{Sensitivity of households' annual total income one year preceding the survey (Y1TI)}

Following regression model is used to determine the impact of various sources of income on annual total income of households one year preceding the survey. Sources of income from sale of various agriculture products including other sources of income (income from the business in few of the cases and remittance income of the households in other cases) are treated as predictors and the annual total income as dependent variable. The regression model is specified as:

$$
\mathrm{Y} 1 \mathrm{TI}=\beta 1 \mathrm{Y} 1 \mathrm{SI} 1+\beta 2 \mathrm{Y} 1 \mathrm{SI} 2+\beta 5 \mathrm{Y} 1 \mathrm{SI} 5+\beta 7 \mathrm{Y} 1 \mathrm{SI} 7+\beta 9 \mathrm{Y} 1 \mathrm{SI} 9+€ \mathrm{i} 1
$$

Where; Y1TI = annual total income one year preceding the survey, $\beta_{\mathrm{i}} \mathrm{s}=$ =regression coefficients.

Y1SI = other sources of income

Y1SI1= crops, Y1SI2= vegetables, Y1SI5= cattle (dairy), Y1SI7= Jobs, Y1SI9= others

$€ \mathrm{i} 1=$ error term

The estimated results of linear regression model between the dependent variable and predictors are given as:

$$
\mathrm{Y} 1 \mathrm{TI}=0.182 \mathrm{Y} 1 \mathrm{SI} 1+0.228 \mathrm{Y} 1 \mathrm{SI} 2+0.109 \mathrm{Y} 1 \mathrm{SI} 5+0.253 \mathrm{Y} 1 \mathrm{SI}+0.912 \mathrm{Y} 1 \mathrm{SI}+€ \mathrm{Ei} 1
$$
.................(Model 1)

While deriving the model 1 variables Y1SI3, Y1SI4, Y1SI6, and Y1SI8 have been excluded due to very insignificant contribution in the model. The estimated Model 1 is significant at 0.00 percent significance level and $\mathrm{F}$ value of the model is 593.368. The adjusted R squared is 0.916.

Model 1 shows that annual total income (YITI) one year preceding the survey was highly dependent (i.e. 0.912) on Y1SI9 (income from foreign employment), followed by income from jobs (0.253, Y1SI7). However, the contribution of sale of various agricultural products, including crops 
(0.182, Y1SI1), vegetables (0.228, Y1SI2) and cattle/dairy (0.109, Y1SI5) was statistically insignificant. The percentage contribution of each sources of income to form a total income includes 10.8 percent of Y1SI1 (crops), 13.5 percent of Y1SI2 (vegetables) 6.4 percent of Y1SI5 (cattle/dairy), 15 percent of Y1SI7 (income from jobs) and 54 percent of Y1SI9 (other sources of income). Hence, the above results lead to conclusion that the role of microfinance to increase the level of annual total income of microfinance client is quite insignificant for experimental group.

\section{Sensitivity of annual total income (Y2ATI) two years preceding the survey}

In order to determine the effects of various sources of income, annual total income preceding two years of the survey following regression model is derived. Sources of income from sale of various agriculture products including other source of income (income from the business in few of the cases and remittance income of the clients in other cases) are considered as predictors and the annual total income as dependent variable. The model is specified as:

$\mathrm{Y} 2 \mathrm{ATI}=\beta 1 \mathrm{Y} 2 \mathrm{SI} 1+\beta 2 \mathrm{Y} 2 \mathrm{SI} 2+\beta 5 \mathrm{Y} 2 \mathrm{SI} 5+\beta 7 \mathrm{Y} 2 \mathrm{SI} 7+\beta 9 \mathrm{Y} 2 \mathrm{SI} 9+€ \mathrm{i} 2$

Where: Y2ATI $=$ annual total income preceding two years of the survey, $\beta_{\mathrm{i}} \mathrm{s}=$ =regression coefficients

Y2SI=sources of income from sale of various products preceding one year of the survey

The estimated results are as given in model 2.

Y2ATI $=0.184 \mathrm{Y} 2 \mathrm{SI} 1+0.110 \mathrm{Y} 2 \mathrm{SI} 2+0.107 \mathrm{Y} 2 \mathrm{SI} 5+0.319 \mathrm{Y} 2 \mathrm{SI}+0.884 \mathrm{Y} 2 \mathrm{SI}++€ \mathrm{i} 1$ (Model 2)

In model 2, Y2SI3, Y2SI4, Y2SI6, and Y2SI8 were excluded because they were statistically insignificant. Model 2 is significant at 0.00 level and F value of the model is 383.206. The adjusted $\mathrm{R}$ squared is 0.883 .

Observing Model 2, it is obvious that the Y2ATI (annual total income preceding two years of the survey) is highly dependent (55\%) on Y2SI9 (other incomes: income from the business in few of the cases, and remittance income of the clients in other cases), followed by income from jobs (Y2SI7) 20 percent. The contribution of sale of various agricultural products including Y2SI1 (crops), Y2SI2 (vegetables), Y2SI5 (cattle/dairy) was insignificant. Contribution of each sources of income to form a total income was 11 percent by Y2SI1 (crops), seven percent each by Y2SI2 (vegetables) and Y2SI5 (cattle/dairy). The results lead to the conclusion that the contribution of 
Socio-economic impact of microfinance in Nepal

households' income, relating to microcredit activities, to uplift the level of annual total income is insignificant.

\section{Inferences from one and two year's preceding regression model}

The results of model 1 and 2 suggest that the level of contribution of Y1SI2 (vegetable farm income) in determining the total income of household is in increasing trend (increased by $6.68 \%$ in a year). This suggests that the income from sale of vegetables in the subsequent years is in increasing trend and rest of the income sources in forming the total income are in declining trend. The results lead to the conclusion that the marginal effect of microfinance in determining the level of total income was in decreasing trend. It is apparent from both the models that the income from other sources (income from the business in few of the cases, and remittance income of the clients in other cases) has also shown a decreasing trend. Overall, the contribution of other incomes in forming the total income of household is very significant in comparison to agriculture and farm income that have raised through the microcredit facilities.

\section{Effects of predictors' on households' net monthly saving}

We have estimated the level of effects of predictors- initial loan amount (ILA), percentage change in income (Y2INCOM), annual total income (Y2ATI), monthly income (Y2MIT) and households monthly expenditure (Y2MET)- on net monthly saving (Y2MST) preceding two years of the survey. Different alternative models are estimated to optimize the effects of predictors- ILA, Y2INCOM, Y2ATI, Y2MIT, and Y2MET- on dependent variable (Y2MST).

Liner regression model (3) is specified to estimate the level of sensitivity of predictors: ILA, Y2INCOM, Y2ATI, Y2MIT, and Y2MET on monthly households net saving (Y2MST) two year preceding the survey.

The estimated results are as given in model 3:

$$
\mathrm{Y} 2 \mathrm{MST}=\beta 1 \mathrm{ILA}+\beta 2 \mathrm{Y} 2 \mathrm{INCOM}-\beta 3 \mathrm{Y} 2 \mathrm{ATI}+\beta 4 \mathrm{Y} 2 \mathrm{MIT}-\beta 5 \mathrm{Y} 2 \mathrm{MET}+€ \mathrm{i} 2
$$

$\mathrm{Y} 2 \mathrm{MST}=0.002 \mathrm{ILA}+0.000 \mathrm{Y} 2 \mathrm{INCOM}-0.001 \mathrm{Y} 2 \mathrm{ATI}+2.014 \mathrm{Y} 2 \mathrm{MIT}-1.438 \mathrm{Y} 2 \mathrm{MET}+€ \mathrm{i} 2$ ...... (Model 3)

Model 3 is significant at 0.00 percent significance level and $\mathrm{F}$ value of the model is 2276 . The adjusted $\mathrm{R}$ squared is 0.976 .

Model 4 is estimated to optimize the result.

$\mathrm{Y} 2 \mathrm{MST}=\beta 1 \mathrm{Y} 2 \mathrm{MIT}-\beta 2 \mathrm{Y} 2 \mathrm{MET}+$ €imst2 
Socio-economic impact of microfinance in Nepal

The results are given in model 4 .

Y2MST = 2.014 Y2MIT - 1.438 Y2MET+€imst2 $\ldots . . . . . . .($ Model 4)

Y2INCOM, Y2ATI, and ILA have been excluded from the model 4 due to co-linearity statistics of 0.951 and 0.981 and 0.969 respectively.

Model 4 is significant at 0.00 percent significance level and $\mathrm{F}$ value of the model is 5751. The adjusted $\mathrm{R}$ squared is 0.976 . While observing model 3 and 4 , it is evident that Model 4 better explains the relationship across the predictors and dependent variables. This implies that net monthly saving (Y2MST) preceding two years of the survey is highly influenced by monthly income and monthly expenditure preceding two years of the survey. The effect of rest of the predictors in the model is either positively or negatively insignificant.

\section{Effects of predictors in estimating land ownership status of household}

Sensitivity of predictors including initial loan amount (ILA), changes in monthly households income in comparison to income (Y2INCOM), annual total income (Y2ATI), monthly income (Y2MIT), monthly expenditure (Y2MET) and monthly net saving (Y2MST) two years preceding the survey are estimated in determining the land ownership status (Y2LWI) two years preceding the survey using the following liner regression model.

$\mathrm{Y} 2 \mathrm{LWI}=\beta_{1} \mathrm{ILA}+\beta_{2} \mathrm{Y} 2 \mathrm{INCOM}+\beta_{3} \mathrm{Y} 2 \mathrm{ATI}+\beta_{4} \mathrm{Y} 2 \mathrm{MIT}-\beta_{5} \mathrm{Y} 2 \mathrm{MET}+\beta_{6} \mathrm{Y} 2 \mathrm{MST}+$ €ilwi

Fitting the value of $\beta$ s in the above model the following results can be obtained:

Y2LWI $=0.023 \mathrm{ILA}+0.022 \mathrm{Y} 2 \mathrm{INCOM}+0.134 \mathrm{Y} 2 \mathrm{ATI}-0.134 \mathrm{Y} 2 \mathrm{MET}+0.167 \mathrm{Y} 2 \mathrm{MST}+$ €ilwi $2 . . . . . . . . . . . . .($ Model 5)

Model 5 is significant at 0.008 percent significance level and $\mathrm{F}$ value of the model is 3.173 . The adjusted R squared is 0.038 . Y2MIT is excluded from the model 5 due to co-linearity statistics (0.006). It helps to conclude that the land ownership status of households is primarily dependent on Y2MST and Y2ATI.

\section{Sensitivity of predictors in estimating the current land ownership status of household}

Sensitivity of predictors, including initial loan amount (ILA), one year preceding the survey net monthly saving (Y1MST) and annual total income (Y1TI) and household current monthly income (Y1HHI) are used to determine the current land ownership status of households (Y1LWI). 
Following liner regression model is developed to determine the level of effect of predictors: ILA, Y1MST, Y1TI and Y1HHI on current land ownership status of household (Y1LWI).

$\mathrm{Y} 1 \mathrm{LWI}=\beta_{1} \mathrm{ILA}+\beta_{2} \mathrm{Y} 1 \mathrm{HHI}+\beta_{3} \mathrm{Y} 1 \mathrm{TI}+\beta_{4} \mathrm{Y} 1 \mathrm{MST}+$ Eilwi $_{1}$

The regression outcomes of the model (6) are as follows:

$\mathrm{Y} 1 \mathrm{LWI}=0.065 \mathrm{ILA}-0.096 \mathrm{Y} 1 \mathrm{HHI}+0.232 \mathrm{Y} 1 \mathrm{TI}+0.140 \mathrm{Y} 1 \mathrm{MST}+€$ ilwi ${ }_{1} \ldots \ldots .($ Model 6)

Model 6 is significant at 0.00 percent significance level and $\mathrm{F}$ value of the model is 6.593 . The adjusted $\mathrm{R}$ squared is 0.075 . While observing the model 6 , it is apparent that Y1LWI is more sensitive on annual total income (Y1TI) and monthly households' net saving (Y1MST) preceding one year of the survey.

\section{Composition of monthly households' expenditure two years preceding the survey}

Effects of predictors including expenditure on poultry business (Y2ME1), bee farm expenses (Y2ME2), vegetable farm expenses (Y2ME4), and expenditure on fertilizer/crops (Y2ME5) are estimated in determining composition of total monthly household expenditure (Y2MET) preceding two years of the survey.

Following liner regression model is established to determine the level of effect of predictors: Y2ME1, Y2ME2, Y2ME4, and Y2ME5 on monthly household expenditure (Y2MET).

$\mathrm{Y} 2 \mathrm{MET}=\beta_{1} \mathrm{Y} 2 \mathrm{ME} 1+\beta_{2} \mathrm{Y} 2 \mathrm{ME} 2+\beta_{3} \mathrm{Y} 2 \mathrm{ME} 4+\beta_{4} \mathrm{Y} 2 \mathrm{ME} 5+$ Eimet $_{2}$

The regression outcomes of the model (6) are as follows:

Y2MET $=0.635$ Y2ME1 + 0.310 Y2ME2+ 0.124 Y2ME4 + 0.391 Y2ME5 + €imet $2 \ldots$ (Model 7)

Model 7 is significant at 0.00 percent significance level and $\mathrm{F}$ value of the model is 2391 . The adjusted $\mathrm{R}$ squared is 0.973 . It is evident from the model 7 that total monthly household expenditure of two years back is composed of different predictors including expenditure on poultry business (Y2ME1), bee firm expense (Y2ME2), vegetable farm expenses (Y2ME4), expenditure related to fertilizer/crops (Y2ME5) and others. The contribution of expenditure from poultry farming, bees firm, vegetable farm and fertilizer/ crops related are 44, 21, 9 and 27 percent respectively on the total monthly households expenditure. Expenditure pattern reveals that the majority of monthly revenue of household tends to be spent in managing poultry business, followed 
by fertilizer and crops related activities. The least amount of total monthly households' expenditure is incurred on operating the vegetable farming related activities.

\section{Composition of monthly households' expenditure preceding one year of the survey}

Effect of predictors including expenditure on poultry business (Y1ME1), bee farm (Y1ME2) vegetable farm (Y1ME4) and fertilizer/crops (Y1ME5) preceding to one year of the survey total monthly household expenditure (Y2MET) is estimated using the following liner regression model:

$\mathrm{Y} 1 \mathrm{MET}=\beta_{1} \mathrm{Y} 1 \mathrm{ME} 1+\beta_{2} \mathrm{Y} 1 \mathrm{ME} 2+\beta_{3} \mathrm{Y} 1 \mathrm{ME} 4+\beta_{4} \mathrm{Y} 1 \mathrm{ME} 5+$ Eimet $_{2}$

The regression outcomes of the model (6) are as follows:Y1MET $=0.764$ Y1ME1 +0.204 Y1ME2+ 0.162Y1ME4 + 0.366 Y1ME5 + €imet 2 (Model 8)

Model 8 is significant at 0.00 percent significance level and $\mathrm{F}$ value of the model is 2.391E3. The adjusted $\mathrm{R}$ squared is 0.973 . It is evident from model 8 that monthly household expenditure preceding one year to the survey is allocated across the farm related activities (predictors) including expenditure on poultry business (Y1ME1), bee firm (Y1ME2), vegetable farming (Y1ME4),fertilizer/crops (Y1ME5) and others. The share of total monthly expenditure is distributed as poultry business (51\%), bee firm (14\%), vegetable farm (11\%) and fertilizer/crops (24\%). Expenditure pattern reveals that majority of monthly revenue of household is spent to manage poultry business, followed by fertilizer/crops related activities. Least amount of total monthly expenditure is allocated to operate the vegetable farm related activities. It is evident from the above results that monthly expenditure relating to poultry business is in increasing trend. The expenditure on fertilizer/crops and bee firm is in decreasing trend.

\section{Level of households earning (ELAM) and the status of male child enrollment in public schools} (MCE1)

Male child school enrollment (MCE1) has not changed significantly with change in level of earning. It signifies that 6 percent of male children are enrolled in public schools. In spite of the change in level of earning, the household ratio declined just by one to reach nine for each male child. It is further evident that number of male children enrollment in public school (MCE1) has slightly increased at the time of more earning. Majority of households either did not enroll their male children in public school (MCE1) or did not provide data on children enrollment irrespective of changes in their level of earning (Annex 7). 
Socio-economic impact of microfinance in Nepal

Changes in level of household earning (ELAM) and the male children enrollment in private schools (MCE2)

The analysis shows (Annex 8) that male child enrollment in private school (MCE2) has changed significantly with the change in level of earning. It gives us sense that one male child is enrolled in private school (MCE2) for 30 percent household in response to increase in income, whereas seven percent households enrolled one male even if they had same level of income over the years. It is further evident that number of male children enrollment in private school (MCE2) slightly increased (two children per household) for seven percent households at the time of high level of earning, whereas three households sent their two male children to private school even if they had same level of their earning. Majority of households either did not enroll their male children in private school (MCE2) or they did not provide the data on children enrollment irrespective of changes in their level of earning.

\section{Level of households earning (ELAM) and status of female children enrollment in public schools (FCE1)}

It is noteworthy that FCE1 did not change significantly with the increase in the level of earning. It implies that six percent households enrolled one female child in public school when income was increased whereas three percent household enrolled one female child in public irrespective of changes in their level of earning. It is further evident that number of female children enrollment in public school (FCE1) has slightly decreased (two children enrolled) for three percent households at the time of high level of earning and four percent households enrolled two children at the same level of earning. A large majority of household (77 percent) either did not enroll their female children in public school (FCE1) or did not provide the child enrollment data irrespective of their changes in level of earning (Annex 9).

\section{Level of households earning (ELAM) and status of female children enrollment (FCE2) in private school}

The results show that (Annex 10) the status of female children enrollment in private school has changed significantly irrespective of level of earning of households. The data reveals that the change in female children enrollment in private school is in progressive trend. Out of total household surveyed, 50 percent of them were able to enroll one female child in private school when their earning had increased. It is further evident that number of female children enrollment in private schools (FCE2) has slightly increased (two children enrolled) for 10.9 percent households at the time of high level of earning. The largest proportion of (46\%) percent households 
(microfinance clients) did not enroll their female children in private schools (FCE2) irrespective of changes in their level of earning $\left(\chi^{2}=55.806, \mathrm{p}<0.001\right)$. The results led to the conclusion that earning from utilization of microfinance loan has encouraged households to enroll their daughters in private schools. Getting enrollment and education from private schools is considered as an advantageous position in Nepal due to their standard of teaching and learning activities in comparison to most of the public schools. Contrasting the above results, it is evident that the enrollment of female and male children in private schools was not affected either with increment in the level of households earning or income remaining in the same level. It also indicates that that there is no disparity in the enrollment of female and male children in private schools though households earning remained stable or rose significantly.

\section{Level of household earning and food sufficiency from household productions (HFSHP)}

The study shows that households' food sufficiency from household production (HFSHP) is ositively related with level of households' earning (ELAM). It is evident that 43 percent households have food sufficiency for 11 months or more from their household productions (Annex 11). HFSHP is for 11 or more months for 43 percent when their level of earning increased, followed by HFSHP for 8-10 months for 39 percent of households. The total percentage of households who have food sufficiency for more than 8 to 10 months was 29 percent, followed by 6-7 months (12\%) and seven percent households had food sufficiency for less than 3 months only.

\section{Relationship between loan payment schedule and interest rate structure}

Observing the analysis table presented in the appendix 11, it is apparent that 66 percent of microfinance clients agreed on monthly payment schedule for their current loan. Out of the monthly scheduled clients, 48 percent clients agreed to pay the interest rate of 18 percent. Of the total surveyed, about 37 percent microcredit clients who had agreed to pay their loan in monthly installment were paying 20 percent interest rate, followed by 11 percent of clients who were paying 22 percent interest rate and three percent of clients in rate of 24 percent. Of the total surveyed, about 16 percent opt for bimonthly payment schedule for their current loan. Among them, 93 percent clients were paying the interest rate of 20 percent. It is evident that 51 percent of clients were paying 20 percent of interest rate, 34 percent paying 18 percent, nine percent paying 22 percent and two percent paying 24 percent interest rate per annum. The results revealed that majority of clients were paying 20 percent of interest rate per annum over their current loan. Interest rate that the majority of microfinance clients are paying is relatively higher than the interest rate charged by most of the commercial banks in Nepal, which is about 16 percent per annum (Annex 12). 
Socio-economic impact of microfinance in Nepal

\section{Major purposes of household saving}

It is apparent that most important purpose of saving for as uttered by 28 percent of micro finance clients is for meeting the future emergency needs (Annex 13). Children education is considered as the second important purposes of saving which contributes for 27 percent of clients followed by provision for future purpose by 25 percent and for future business expansion by 19 percent. The analysis explores that majority of clients maintain their savings from the current earning to meet the future emergency needs. Saving for future business expansion is considered as the least preferred purpose.

\section{Major purposes and focuses of microcredit}

The primary purposes (LPP) and secondary purpose (LSP) of the loan vary among the clients. Around 35 percent microcredit clients have taken loan from microfinance institutions for small enterprises followed by for the purpose of fertilizer and seeds (23\%), working capital loan (21\%), buying animals (8.8\%) and tools and equipment purchase (6.4\%). Very few (3.9\%) microcredit clients have taken loan from microfinance institutions for the purpose of buying land. Of the total clients surveyed, 46 percent microcredit clients did not mention their secondary purpose of loan, 29 percent took loan to buy cattle as a secondary purpose of loan and 17 percent of clients have taken loan from microfinance institutions for indigenous business.

It is obvious from the above analysis that majority of microcredit clients preferred loan for other purposes rather than for agriculture. Very few households have taken agricultural loan as a primary loan.

\section{Severities of problems faced by microfinance clients (SPs)}

The Annex 14 exhibits the severities of various types of problems faced by the microfinance clients. The researcher has identified the different severities of the problems of the microfinance clients, which includes; lack of access to working capital (SP1), lack of access to loans for acquisition of capital assets (SP2), lack of marketing skills (SP3), difficulty in maintaining market share (SP4), lack of management capacity (SP5), deficient product packaging (SP6), lack of trained personnel (SP7), lack of basic bookkeeping (SP8), lack of access to markets (SP9).

Regarding the severities of problem, 29 percent microcredit clients did not experience lack of access to working capital (SP1) for their business activities. Very small proportion (1.1\%) had faced severe problems on micro finance. Of the total, 16 percent clients perceived SP1 as an average problem and 38 percent perceived access to working capital as the minor problem. A 
negligible proportion (0.4\%) perceived SP1 as a major problem. Of the total respondents, 16 percent clients did not mention their severity of problem (SPs).

Regarding the problem of the lack of access to loans for acquisition of capital assets (SP2), 35 percent perceived it as a little problem, followed by average problem (10\%) whereas six percent did not experience this kind of problem. Out of total households surveyed, eight percent faced it as a severe problem whereas 39 percent did not respond on the problem. Regarding the lack of marketing skills problem (SP3), it is clear from the current study that 26 percent of household perceived SP3 as a minor problem and perceived it as an average problem by 24 percent while nine percent of household clients considered this as not a problem.

\section{Discussion and conclusion}

The microfinance industry is characterized by too many small-scale suppliers with a relatively large potential market. Although institutional diversity is generally an important characteristic of a robust microfinance industry, institutional proliferation cannot necessarily be considered good for healthy growth and development of microfinance industry. The main purpose of the current study was to explore the effects of microfinance on socio-economic status of Nepali households. The study reports that the current monthly income of few of the households (control group) is in declining trend in comparison of one year preceding income with two year preceding. But, we have not examined the reasons of decline in household income and it can be the scope for future study. The household food sufficiency from household production is higher in experimental group (who practiced the MF) than the control group (who do not practice MF).

It is further highlighted from the analysis that two years back net monthly saving of households was highly influenced by preceding two years of monthly income and monthly households' expenditure. Effects of rest of the predictors either positively or negatively were not significant. Preceding one year of annual total income of households is highly dependent on other incomes, followed by income from jobs. The contribution of sale of various agricultural products, including crops, vegetables and cattle/dairy were very insignificant. The study observed that the role of microfinance related activities in increasing the level of annual total income of households is very insignificant. This conclusion has been drawn while comparing the microfinance income with regard to income from other sources, which constitutes the part of the total income of the clients (income from business in few cases and remittance income in most of the cases).

The findings of the study show that the level of income from other sources (business and remittance) has been gradually decreased, from year after the year, very insignificantly. Overall, the contribution of non-micro finance incomes in the total income of household is very significant in comparison to income raised through the microcredit facilities. The relationship between expenditure of consumable goods and expenses other than the regular expense is negative. The net 
monthly saving statistics is in declining trend for the MF practitioner (experimental group) compared to the non-practitioner of MF (control group).

Findings also show that the current land ownership status of households is very insignificantly explained by the predictors including annual total income, net monthly saving, initial loan amount, and households' current monthly income. In addition, monthly expenditure pattern of households reveal that the significant part of monthly revenue was spent to manage poultry business, followed by fertilizer and crops related activities. Least amount of expenditure was incurred to operate the vegetable farm related activities.

It concludes that expenditure on fertilizer/crops related expenditure and expenditure relating to bee firm were in decreasing trend. This indicates that the microcredit activities have promoted the activities relating to poultry business in line with other micro enterprise related activities. The increase in the household earning has encouraged enrolling daughters in private school. Further, the household earning has brought positive impact in increasing the length of food sufficiency of households.

In line with the conclusion drawn by Duvendack, Palmer-Jones et al. (2011) with doubts about research designs and analytical methods used by various microfinance studies, we can neither support nor deny the notion that microfinance is pro-poor and pro-women. The marginal effect of microfinance in determining the level of households' total income is in decreasing trend in the subsequent years in comparison to the preceding years. Author could not explore the reasons behind the above findings, but the facts reveal the above truth. This could be the scope of future study. Despite of the large number of the poor depending on semiformal rural finance institutions, the majority of the microfinance institutions are capacity constrained in key technical areas essential to rural finance operations such as accounting, auditing and strategic planning. Lack of observation significantly limits their potential to expand their client base and outreach to poor

households. Hence the regulator should insist in expanding their technical capacity, so that they can provide more better and reliable services to the prospective and current microfinance clients.

\section{References}

Asian Development Bank [ADB]. (2010). Rural finance sector development cluster programme subprogram II. Kathmandu: ADB.

Banerjee, A., Duflo, E., Glennerster, R. \& Kinnan, C. (2009). The miracle of microfinance? Evidence from a randomized evaluation. Retrieved 15 April 2013 from http://www.povertyactionlab.org/publication/miracle-microfinance-evidence-randomizedevaluation.

Dhakal, N. H. (2007). Towards expanding the frontier of microfinance services in Nepal. $\begin{array}{llll}\text { Retrieved } & 10 & \text { February } & 2013\end{array}$ 
http://www.fao.org/ag/rurfinconference/docs/papers_theme_2/towards_expanding_the_fro ntier.pdf.

Duvendack, M., Palmer-Jones R., Copestake J. G., Hooper L., Loke Y. \& Rao, N. (2011). What is the evidence of the impact of microfinance on the well-being of poor people? Retrieved 10 March 2013 from http://www.givedirectly.org/pdf/DFID_microfinance_evidence_review.pdf.

Microfinance Focus (2009). Microfinance and sustainable development. A global monthly Emagazine.

Nepal Rastra Bank [NRB]. (2008). Micro-financing towards empowerment of disadvantaged groups in Nepal: Innovations and practices. Kathmandu: NRB. 
Socio-economic impact of microfinance in Nepal

Annex 1: Predictors of households' total annual total income one year preceding the survey (Y1TI)

\begin{tabular}{lrrr}
\hline Predictors & Standardized $\beta$ & $\mathrm{t}$ & Sig. \\
\hline Y1SI1 & .182 & 9.994 & .000 \\
Y1SI2 & .228 & 12.425 & .000 \\
Y1SI5 & .109 & 6.225 & .000 \\
Y1SI7 & .253 & 14.320 & .000 \\
Y1SI9 & .912 & 51.322 & .000 \\
F & 593 & & .000 \\
Adjusted R & & & .000 \\
\hline
\end{tabular}

Annex 2: Predictors of households' total annual income (Y2ATI) two years preceding the survey

\begin{tabular}{lrrr}
\hline Predictors & Standardized $\beta$ & $\mathrm{t}$ & Sig. \\
\hline Y2SI1 & .184 & 8.241 & .000 \\
Y2SI2 & .110 & 4.682 & .000 \\
Y2SI5 & .107 & 4.638 & .000 \\
Y2SI7 & .319 & 14.468 & .000 \\
Y2SI9 & .884 & 40.426 & .000 \\
F & 593 & & .000 \\
Adjusted R & .883 & & .000 \\
\hline
\end{tabular}


Socio-economic impact of microfinance in Nepal

Annex 3: Predictors of households' net monthly saving two years preceding the survey (Y2MST)

\begin{tabular}{lrrr}
\hline Predictors & Standardized $\beta$ & $\mathrm{t}$ & Sig. \\
\hline Model I & & .212 & .833 \\
\hline ILA & .002 & -.032 & .975 \\
Y2INCOM & .000 & -.121 & .904 \\
Y2ATI & -.001 & 97.984 & .000 \\
Y2MIT & 2.014 & -70.213 & .000 \\
Y2MET & -1.438 & & .000 \\
F & 2276 & & .000 \\
Adjusted R & & & \\
\hline Model II & .976 & & .000 \\
\hline Y2MIT & & 100.239 & .000 \\
Y2MET & 2.013 & -71.580 & \\
F & -1.438 & & \\
Adjusted R & & & \\
\hline
\end{tabular}

Annex 4: Predictors of land ownership status of household (Y2LWI)

\begin{tabular}{lrrr} 
Predictors & Standardized $\beta$ & $\mathrm{t}$ & Sig. \\
\hline ILA & .023 & .365 & .716 \\
Y2INCOM & .022 & .356 & .722 \\
Y2ATI & .134 & 2.096 & .037 \\
Y2MET & -.134 & -2.054 & .041 \\
Y2MST & .167 & 2.599 & .010 \\
F & 3.173 & & .000 \\
Adjusted R & & & .000 \\
\hline
\end{tabular}


Annex 5: Predictors of the current land ownership status of household (Y1LWI)

\begin{tabular}{lrrr}
\hline Predictors & Standardized $\beta$ & $\mathrm{t}$ & Sig. \\
\hline ILA & .023 & .365 & .716 \\
Y2INCOM & .022 & .356 & .722 \\
Y2ATI & .134 & 2.096 & .037 \\
Y2MET & -.134 & -2.054 & .041 \\
Y2MST & .167 & 2.599 & .010 \\
F & 3.173 & & .000 \\
Adjusted $\mathrm{R}^{2}$ & 0.038 & & .000 \\
\hline
\end{tabular}

Annex 6: Predictors of monthly households' expenditure two years preceding the survey (Y2MET)

\begin{tabular}{lrrr} 
Predictors & Standardized $\beta$ & $\mathrm{t}$ & Sig. \\
\hline Y2ME1 & .635 & 59.898 & .000 \\
Y2ME2 & .310 & 27.685 & .000 \\
Y2ME4 & .124 & 12.141 & .000 \\
Y2ME5 & .391 & 35.793 & .000 \\
F & 2391 & & .000 \\
Adjusted R ${ }^{2}$ & .937 & & .000 \\
\hline
\end{tabular}

Annex 7: Household earning and male children enrollment in public school (N=282)

\begin{tabular}{lrrrrrr}
\hline Household earning & \multicolumn{5}{c}{ Number of male children enrollment } & Total \\
\cline { 2 - 5 } compared to past & 0 & 1 & 2 & 3 & 4 & \\
\hline Earn more & 49.3 & 3.5 & 3.9 & 1.4 & 0.0 & 58.2 \\
Earn less & 9.9 & 1.8 & 2.1 & 0.0 & 0.0 & 13.8 \\
Earn about the same & 17.0 & 3.2 & 3.5 & 0.7 & 0.7 & 25.2 \\
Not sure & 1.4 & 0.4 & 0.0 & 0.0 & 0.0 & 1.8 \\
Not stated & 1.1 & 0.0 & 0.0 & 0.0 & 0.0 & 1.1 \\
Total & 78.7 & 8.9 & 9.6 & 2.1 & 0.7 & 100.0 \\
\hline
\end{tabular}


Socio-economic impact of microfinance in Nepal

Annex 8: Household earning and male children enrollment in private school in \% ( $\mathrm{N}=282)$

\begin{tabular}{lrrrrrr}
\hline Household earning & \multicolumn{5}{c}{ Number of female children enrollment } & Total \\
\cline { 2 - 5 } compared to past & 0 & 1 & 2 & 3 & 4 & \\
\hline Earn more & 20.2 & 30.1 & 7.1 & 0.7 & 0.0 & 58.2 \\
Earn less & 5.7 & 6.0 & 1.4 & 0.4 & 0.4 & 13.8 \\
Earn about the same & 14.9 & 7.1 & 3.2 & 0.0 & 0.0 & 25.2 \\
Not sure & 0.0 & 1.4 & 0.4 & 0.0 & 0.0 & 1.8 \\
Not stated & 0.0 & 0.7 & 0.4 & 0.0 & 0.0 & 1.1 \\
Total & 40.8 & 45.4 & 12.4 & 1.1 & 0.4 & 100.0 \\
\hline
\end{tabular}

Annex 9: Household earning and female child enrollment in public school in \% ( $\mathrm{N}=282)$

\begin{tabular}{lrrrrrr}
\hline Household earning & \multicolumn{5}{c}{ Number of female children enrollment } & Total \\
\cline { 2 - 5 } compared to past & 0 & 1 & 2 & 3 & 4 & \\
\hline Earn more & 47.2 & 6.0 & 3.2 & 1.8 & 0.0 & 58.2 \\
Earn less & 10.6 & 1.4 & 1.8 & 0.0 & 0.0 & 13.8 \\
Earn about the same & 17.4 & 3.2 & 4.3 & 0.4 & 0.0 & 25.2 \\
Not sure & 1.1 & 0.4 & 0.4 & 0.0 & 0.0 & 1.8 \\
Not stated & 1.1 & 0.0 & 0.0 & 0.0 & 0.0 & 1.1 \\
Total & 77.3 & 11.0 & 9.6 & 2.1 & 0.0 & 100.0 \\
\hline
\end{tabular}

Annex 10: Households earning and female children enrollment in private school $(\mathrm{N}=282)$

\begin{tabular}{lrrrrrr}
\hline Household earning & \multicolumn{5}{c}{ Number of female children enrollment } & Total \\
\cline { 2 - 5 } compared to past & 0 & 1 & 2 & 3 & 4 & \\
\hline Earn more & 19.5 & 29.1 & 6.7 & 3.2 & 0.0 & 58.5 \\
Earn less & 9.2 & 2.8 & 1.1 & 0.7 & 0.0 & 13.8 \\
Earn about the same & 16.0 & 6.4 & 2.5 & 0.4 & 0.0 & 25.2 \\
Not sure & 0.7 & 0.7 & 0.0 & 0.0 & 0.0 & 1.4 \\
Not stated & 0.0 & 0.0 & 0.4 & 0.7 & 0.0 & 1.1 \\
Total & 45.4 & 39.0 & 10.6 & 5.0 & 0.0 & 100.0 \\
\hline
\end{tabular}


Annex 11: Household earning and food sufficiency in \% ( $\mathrm{N}=282)$

\begin{tabular}{|c|c|c|c|c|c|c|c|}
\hline \multirow{2}{*}{$\begin{array}{l}\text { Household earning } \\
\text { compared to past }\end{array}$} & \multicolumn{6}{|c|}{ Food sufficiency in months } & \multirow[b]{2}{*}{ Total } \\
\hline & $<3$ & $3-5$ & $6-7$ & $8-10$ & $11+$ & Not stated & \\
\hline Earn more & 3.5 & 1.4 & 3.5 & 23.0 & 24.8 & 2.1 & 58.2 \\
\hline Earn less & 1.1 & 0.4 & 2.5 & 0.4 & 7.1 & 2.5 & 13.8 \\
\hline Earn about the same & 2.5 & 1.8 & 5.7 & 5.3 & 9.2 & 0.7 & 25.2 \\
\hline Not sure & 0.0 & 0.0 & 0.0 & 0.4 & 1.4 & 0.0 & 1.8 \\
\hline Not stated & 0.0 & 0.0 & 0.4 & 0.4 & 0.0 & 0.0 & 0.7 \\
\hline Total & 7.1 & 3.5 & 12.1 & 29.4 & 42.6 & 5.3 & 100.0 \\
\hline
\end{tabular}

Annex 12: Interest rate (IR) structure and payment schedule for current loan in \% ( $\mathrm{N}=282)$

\begin{tabular}{lrrrrrrrr}
\hline & \multicolumn{1}{c}{ Interest rate (in \%) } \\
Payment schedule & 0 & 9 & 15 & 18 & 20 & 22 & 24 & Total \\
\hline Monthly & 0.4 & 0.0 & 0.0 & 31.9 & 23.8 & 7.4 & 2.1 & 66.0 \\
Every two weeks & 0.4 & 0.0 & 0.0 & 0.4 & 14.9 & 0.4 & 0.0 & 16.0 \\
Twice per month & 0.0 & 0.0 & 0.4 & 0.0 & 1.1 & 1.4 & 0.0 & 2.8 \\
Other & 2.1 & 0.4 & 0.0 & 1.1 & 10.6 & 0.0 & 0.0 & 14.2 \\
Not stated & 0.0 & 0.0 & 0.0 & 0.7 & 0.7 & 0.0 & 0.0 & 1.4 \\
Total & 2.8 & 0.4 & 0.4 & 34.0 & 51.1 & 9.2 & 2.1 & 100.0 \\
\hline
\end{tabular}

Annex 13: Purpose of household saving in \% (N=282)

\begin{tabular}{lr} 
Purpose of household saving & Percentage \\
\hline Saving for future & 25.2 \\
Future emergency needs & 27.7 \\
Future business expansion & 19.1 \\
Children's education & 26.6 \\
Not stated & 1.4 \\
Total & 100 \\
\hline
\end{tabular}


Socio-economic impact of microfinance in Nepal

Annex 14: Micro-finance related problems in \% ( $\mathrm{N}=282)$

\begin{tabular}{lrrrrrrrr}
\hline Severity of problem & \multicolumn{7}{c}{ Severity of Problem(SPs) } \\
\cline { 2 - 9 } & \multicolumn{1}{c}{ SP1 } & \multicolumn{1}{c}{ SP 2 } & SP 3 & SP 4 & SP 5 & SP 6 & SP 7 & SP 8 \\
\hline No problem & 29.3 & 6.4 & 9.3 & 7.8 & 7.4 & 5.7 & 6.7 & 7.1 \\
Little problem & 37.8 & 35 & 25.7 & 24.1 & 16.3 & 16.4 & 16.7 & 17.4 \\
Average problem & 15.5 & 10.2 & 23.6 & 23.4 & 22 & 16.7 & 18.8 & 20.6 \\
High problem & 0.4 & 1.4 & 2.1 & 2.5 & 4.3 & 4.3 & 6.7 & 8.2 \\
Severe problem & 1.1 & 7.8 & 2.1 & 2.1 & 1.8 & 0.7 & 2.8 & 1.8 \\
No response & 15.9 & 39.2 & 37.1 & 40.1 & 48.2 & 56.2 & 48.2 & 45 \\
Total & 100 & 100 & 100 & 100 & 100 & 100 & 100 & 100 \\
\hline
\end{tabular}

